\title{
YOUTH CORRECTION AUTHORITY IN ACTION: THE CALIFORNIA EXPERIENCE
}

\author{
KaRL HoltoN*
}

In the summer of I94I the American Law Institute sent drafts of its model Youth Correction Authority Act to interested persons in the State of California. Through the efforts of Mr. John R. Ellingston a statewide committee was formed with subcommittees in both Northern and Southern California. On these committees were representatives of the bench, the bar, the legislature, social agencies, probation officers, psychiatrists, etc. After the model act had been given careful study, Assemblyman James H. Phillips from Alameda County introduced an adaptation of the act in the I94I legislature.

For some months prior to the introduction of this bill, there had been a great deal of criticism relative to the management of the Whittier State School, an institution for younger boys. There had also been some very adverse criticism of the parole system, and the management of at least one of the state penitentiaries. As a result of these months of criticism, women's clubs, service clubs, bar associations, and civic groups over the state generally were receptive to the basic principles set forth in the Youth Correction Authority Act.

The legislation was skilfully handled by Assemblyman Phillips and passed both houses with practically no opposition. It was immediately signed by the Governor.

In most respects the California act ${ }^{1}$ follows very closely the model act proposed by the American Law Institute. The major differences are:

I. The model act provides for all members to be appointed by the Governor for a term of nine years. The California act provides for an advisory panel consisting of the presidents of the California Conference of Social Work, the Probation and Parole Officers' Association, the State Bar Association, the California Medical Association, and the Prison Association. This advisory panel initially is to recommend six persons to the Governor for membership on the Youth Authority. From this list of six the Governor must choose two. The third member of the Authority is to be the Governor's own choice. In California the Governor selected a third man who was

- A.B., 1923, University of Washington; graduate study, University of Southern California. Chief Probation Officer, Los Angeles County; member of the California Youth Correction Authority. Formerly Chicf of the Juvenile Division of the Los Angeles County Probation Department. Chairman or member of numerous committecs in the field of social work; past president of the California Probation and Parole Officers' Association.

${ }^{2}$ Calif. Welfare and INst. Code (Deering, z941 Supp.) $\$ \$ 1700-1783$. 
not one of the six persons nominated by the panel but was a man whose qualifications were endorsed by them.

2. Under the model act the judge may not grant probation to persons coming within the age range accepted by the Authority. Under the California act but not the model act, the courts may grant probation to this age group and may also impose jail sentences up to ninety days. Under both acts, the judge may impose a life sentence or may sentence to death.

3. In the model act the Authority is empowered to accept persons $x 6$ years and over from the Juvenile Court. In California there is no lower age limit. The Authority may accept any boy or girl from the Juvenile Court if the court cares to commit and if the Authority cares to accept.

4. The model act provides that persons who are found to have been less than 2 I years of age at time of apprehension shall be committed to the Youth Authority. In the California act the age is changed to less than 23 at time of apprehension.

5. The California act makes as one of the principal duties of the Authority the responsibility for establishing or assisting in establishing public councils or committees having to do with delinquency prevention. This is an important addition and should make the act more valuable.

6. The California act gives the Youth Authority until January I, I944, to get ready to accept commitments from the courts. Until that time the Authority may limit the number of cases it will accept. After that date all cases committed by the courts must be accepted.

The legislature set the salaries of the three board members at $\$ 10,000$ per year and appropriated a total of $\$ 100,000$ for the functioning of the Authority for the next biennium.

The advisory panel met and made its recommendations to the Governor. From the recommended list the Governor appointed O. H. Close, Superintendent of the Preston School of Industry at Ione, and Karl Holton, Chief Probation Officer of Los Angeles County, the author of this article. As his own choice he appointed Harold A. Slane, Deputy City Attorney of Los Angeles. Mr. Slane had been interviewed by the panel and was endorsed by them.

Since only \$100,000 had been appropriated to accomplish the purposes of the act in a state of the size and population of California, neither Mr. Close nor Mr. Holton felt that he could accept the appointment and draw the salary because if these salaries were paid there would not be sufficient funds available for much else. Both men declined appointment. In the special session of the legislature in January 1942 the California act was amended so as to make it possible for Mr. Close and Mr. Holton to accept appointments as members of the Authority without compensation. The amended act also made it possible for them to continue with their regular work. The California board thus consists of two members who devote part time without salary, and one full-time paid member.

On January 23, 1942, the Youth Authority members met for the first time and 
organized the board. Mr. O. H. Close was elected chairman. A headquarters office was set up in Sacramento with branch offices in Los Angeles and San Francisco.

What was the task facing this board, and what could it hope to accomplish with the $\$ 100,000$ at its disposal? The Youth Authority had to

I. Prepare to accept, as required by the law, all cases committed to it by January $x$, I944, in the age group under 23 .

2. Draw up the necessary legal forms of commitment by the courts to it, and by the Authority to the institutions and agencies which it intended to use.

3. Provide for temporary places of detention, for necessary diagnostic clinics, for the hiring of personnel to supervise and carry out its functions.

4. Study existing facilities for correction and treatment within the state, and be prepared to make definite recommendations relative to additional facilities which would be needed.

5. Create administrative districts suitable for the performance of its duties.

6. Assist in a statewide delinquency prevention program.

What has the Authority been able to do so far, and has any of the work done been of real value to the State of California? In evaluating the following brief summary of the accomplishments of the California Youth Correction Authority to date, the reader should remember that the Japanese attacked Pearl Harbor on December 7, I94I, that the Authority had its first meeting on January 23, 1942, and that the total sum appropriated to operate the Authority up to and including June 30, r943, was $\$ 100,000$. Moreover, conditions have changed rapidly in the past few months; it is difficult to make plans for even well-established agencies; it is almost impossible to secure materials or supplies for new projects. Competent personnel is also increasingly hard to find and to keep.

At its first meeting, after Mr. Close was elected as chairman, the Authority began to plan for the establishment of its own diagnostic unit where some thirty boys could be received, studied, and cared for at one time. The minutes show that from its inception the Authority intended to make this diagnostic unit of as much service to the state as possible. Having little money of its own the Authority used its broad contractual powers to obtain a separate building on the grounds of the Preston School of Industry where the diagnostic clinic could be established. A building was available for housing, and the kitchen, hospital, laundry, and other institutional services of Preston could be obtained at little cost. The Authority had to secure its own personnel for the staffing of this unit.

A very competent court clerk and other clerical aids were immediately hired and, with the help of the Attorney General and of the Director of Finance, an office was established, operating rules approved, contracts drawn, an operating budget set up, and all of the other ground work was done which was necessary in order to begin functioning as an organization.

A nationwide examination was held for clinical psychologist and Dr. Burton F. Castner was No. I on the list; he reported for work at the diagnostic unit of the 
Authority on August 15. Dr. Castner has a fine background of experience, both at Yale University and at the Annandale Farms in New Jersey.

Due to the current shortage of psychiatrists, it has to date been impossible to find a well-qualified man for that important position. Arrangements have therefore been made with Dr. Smythe and Dr. Conzelmann at Stockton State Hospital whereby Dr. Conzelmann will give a portion of his time to the Youth Authority. Supervisory staff, a teacher, and psychiatric social workers have been interviewed and are being employed.

To this unit 22 boys have already been committed from various courts throughout the state. The formal announcement that the Authority can take a limited number of commitments is just now being forwarded to all of the courts. Interestingly enough, so far many of the requests for commitment are coming from Juvenile Court judges of smaller counties. Justice, Municipal and Superior Court judges handling criminal matters are, of course, interested, and many more commitments will be submitted than the Authority can accept at present. The Authority is attempting to select cases from counties where facilities are very few. It is also attempting to take only cases that are difficult to deal with and for whom regular state institutions are not now readily available.

One of the first cases accepted was that of a fourteen-year-old boy who had been sentenced to San Quentin Penitentiary for murder. The committing judge, the warden of San Quentin, the Board of Prison Directors, and the Governor of the state all requested the Youth Authority to take this boy. His sentence was commuted by the Governor and he was regularly committed to the Authority. His case has been very carefully studied, and he is now being cared for with boys of his own age group in a correctional institution which has a program suited to his needs.

This clinic can take care of thirty boys at one time. After they are studied many of them can very quickly be committed by the Authority to existing institutions, or private agencies, or released on probation. Others will have to be studied over a period of time.

By this method of operation the Authority is using the diagnostic unit as a miniature Youth Correction Authority. It provides a way to test out the clinic itself and the clinic personnel; it provides an additional state facility not heretofore available; it limits the use of this new facility to the counties and to the courts and to the young men who need its services most. Through the use of this diagnostic unit the Authority can test the legality of the forms it is using for commitment to the various institutions and agencies throughout the state. It can also test procedure and commitment forms from committing courts. It can in this way establish a sound procedural and legal basis for its operation when the time comes when it must accept all of the cases from all of the courts throughout the state. When that time comes the Authority will have all of the trouble it wants without looking for it.

When the Authority had its first meeting and began to estimate what the case load might be on January I, I944, it found that there were no figures which would 
form the basis for even an intelligent guess as to how many cases might be committed to it. The Authority entered into a contract with the National Youth Administration whereby a very simple survey would be made of all of the courts in all of the counties in California to discover how many young men and women had gone through each court in I94x, what they were arrested for, what they were convicted of, their age, sex, race, nationality, and the sentence imposed. While this survey was in process the National Youth Administration was forced to cancel the contract. The Youth Authority then hired its own personnel and now has the survey practically completed. Reports have been received from more than $98 \%$ of the courts. A few small courts have not been visited and they have not responded to the questionnaire mailed to them. Within the next thirty days this survey will be finished and the figures will be broken down by courts, by types of offenses, by age groups, by counties, etc. ${ }^{2}$ With these I94I figures as a basis the Authority can make some estimate of the case load it must expect when all of the courts begin to commit to it. This survey will be useful not only to the Authority but to many other agencies and departments throughout the state.

For some time the Whittier State School had been sharply criticized by newspapers and civic organizations throughout the state. Several efforts had been made by the Department of Institutions to reorganize this school. For one reason or another none of these efforts seemed to bring about the desired results. Because of long continued criticism and staff demoralization the school was not functioning effectively. A great many boys ran away from the institution, and the population . had dropped from approximately $35^{\circ}$ to less than 200. This drop in population occurred in spite of the very urgent need of the state for even more beds than the institution could normally provide. In the spring of 1942 there were so many escapes from the institution and so many serious offenses committed in the town of Whittier by the boys who had escaped that an Assembly Interim Committee, the Chamber of Commerce in Whittier, and other organizations insisted that either conditions be improved or the school closed.

On April 10, 1942, the Governor called the Youth Correction Authority members to meet in his office with Dr. Aaron J. Rosanoff, Director of the State Department of Institutions. With the full consent of Dr. Rosanoff and at the request of the Governor the Youth Correction Authority agreed to assume the responsibility for the management of the three correctional schools-Whittier State School, Preston School of Industry, and Ventura School for Girls. The Authority was to make recommendations as to the employment of all personnel and as to policy and procedure. The understanding with the Director of Institutions was that all important matters would be cleared with him but that recommendations made by the Authority would be followed. The first conference was with members of the State Personnel Board who

\footnotetext{
${ }^{3}$ The survey having been brought still closer to completion before it became necessary to send Mr. Holton's article to the press, he kindly consented to permit the publication of the accumulative figures by state totals prior to the publication of the report in final form. The data are published in an anpendix to Mr. Holton's article, infra p. 663. ED.
} 
agreed to order an examination for a permanent superintendent of Whittier immediately. The qualifications for the position were approved by the Personnel Board, the Director of Institutions, and the Youth Authority. While the examination was being prepared and notices sent out so that applicants could be secured, the Authority proceeded to work with the very fine Assistant Superintendent who was in charge of the school, Gerald F. Spencer. Mr. Spencer and other staff members were assured that the Authority was concerned only with improving conditions at the school and intended to work out programs with the staff so that the purposes for which the school was founded could be carried out.

In order to get an objective evaluation of the school and of its personnel the Authority borrowed Paul J. McKusick, Assistant State Director of Probation. Mr. McKusick had a fine educational and experience background and was known and liked by every probation officer and judge in the state. He is young, progressive, and well qualified. He was sent to Whittier as the representative of the Youth Correction Authority and instructed to work with and through the Acting Superintendent, Mr. Spencer. After about three months residence at Whittier Mr. McKusick, with the full cooperation of Mr. Spencer and other members of the staff, was able to reorganize the school's program and to regain in a large measure the support of the community and to reestablish staff morale. Mr. McKusick became very much interested in the institution during the period of the survey and finally agreed to take the examination for superintendent. In a statewide civil service examination he placed on the eligible list, and on the recommendation of the Authority was appointed permanent superintendent by the Director of Institutions.

At the present time the Whittier State School is filled to capacity. During the last month only one boy escaped. An excellent school principal has been hired, a good maintenance engineer has been brought in, and other fine staff additions have been made. For several weeks now all newspaper comments about the school have been favorable. In spite of the difficulties of operating an institution during wartime we are all hopeful that the program at Whittier is again accomplishing its purpose of rehabilitation and training, and that the school is on the way back to the fine national reputation it once enjoyed.

Dr. Olive P. Walton, Superintendent of the Ventura School for Girls, is retiring from that institution on November I, I942. This is the only state correctional school for girls in California. Dr. Walton has been a fine superintendent and it should be easy for a competent person to take her place when she retires. Dr. Walton has felt for some time that certain aspects of the school's program should be changed, liberalized, and modernized, but she has not felt that she was able to undertake such a reorganization. With the full consent of the Director of Institutions and of Dr. Walton the Youth Correction Authority employed Mrs. Ruby Inlow, of the Graduate School of Social Work of the University of Southern California, to live at Ventura during July and August of this year and make an objective study of the program and of the staff. Mrs. Inlow has a fine educational and experience background, and had approximately two years experience doing research work with Dr. Dill in the 
boys' institution in Indiana. Because Mrs. Inlow is a sincere, conscientious person with great ability to work with people she was quickly able to get the full cooperation not only of the superintendent at Ventura but of all staff members. She lived in the cottages with the girls, talked to them, came to know practically all of the employees, made a detailed study of approximately half of the cases committed to the institution, visited parolees with the parole officer, talked with the parents of paroled girls, and talked with the paroled girls themselves. She has just completed her written report which gives one of the finest and fairest evaluations of an institutional program it has been my privilege to read. The State Personnel Board is conducting an examination on October 5 from which will be selected the best qualified person for superintendent that can be found. After this superintendent is selected we feel that Mrs. Inlow's report and recommendations and the advice of Dr. Walton will aid the new superintendent, the Director of Institutions, and the Youth Authority in making the program at Ventura of the greatest possible value to the girls who are committed there.

The forestry camps operated by Los Angeles, Kern, and San Diego County Probation Departments in cooperation with their respective forestry departments have received wide recognition. In these camps there is a simple program with a worthwhile work project of reforestation, road building, fire fighting, etc., that has proved very successful in the adjustment of 16 - and 17 -year-old boys who have short delinquency records and who need to be removed from the community and placed in an environment where they can be taught to work, to face responsibility, and where their whole attitude toward life can be made more wholesome. Only the larger counties can operate such camps because of the cost. Unless a camp can have an average population of at least sixty boys the overhead cost makes their establishment impractical. For this reason smaller counties are not able to have this type of facility. The CCC camps have closed, making the services of their enrollees as firefighters no longer available. In the California forests fire is an ever-present hazard during the summer. There is also a great deal of reforestation and trail maintenance work to be done which is of real value and service to the state. The Youth Authority has entered into agreements with federal and state agencies and will be ready next spring to open up several camps for boys who will benefit from this type of program. These camps will be available to boys from all counties and will be of material assistance to the forestry departments.

The Authority is also developing plans for the possible use of some of these boys as agricultural laborers in areas where farm labor is so badly needed. They can be housed in the camps, supervised by a properly selected staff, and their work will be of great value to the state and to the nation.

Several years ago the Department of Institutions established a division known as the California Bureau of Juvenile Research. This Bureau had traveling clinics which gave valuable service to school authorities, private agencies, and probation officers, particularly in the smaller counties throughout the state. The Bureau of Juvenile Research successfully operated for several years, but three years ago as an economy measure the Bureau was eliminated. In its files are the records of several thousand 
cases which were studied. Many of these boys and girls are still in the community, and some of them are still problem cases. The Authority has entered into a contract with Dr. Norman Fenton, who was the Director of the Bureau of Juvenile Research, to employ him on a part-time basis so that the work done for many years by the Bureau of Juvenile Research will not be lost. The records will be moved to the Youth Correction Authority office and Dr. Fenton will resume part-time work in several of the counties where his services are most needed. His work will be coordinated with the work of the diagnostic clinic headed by Drs. Castner and Conzelmann. With the consent of Stanford University, where Dr. Fenton is teaching, the Authority hopes to be able to develop workshop programs where teachers, social workers, probation officers, and others interested in delinquency prevention can come and realistically study the problems facing them in their communities. Through this combination of workshop, traveling clinic, and diagnostic study clinic the Authority hopes to be able to be of material assistance in a statewide delinquency prevention program.

In addition to the projects above mentioned the Authority members have taken part in innumerable state conferences and meetings, have met with local committees, judges, probation officers, and social workers to study delinquency problems throughout the state. Mr. Holton and Mr. Slane are working closely with the Judge of the Juvenile Court, the Probation Office, and other agencies in Los Angeles in an attempt to solve the so-called Mexican gang problem in that city. Much progress has been made.

The taxpayers will be interested to know that there is still sufficient money left in the budget to house, feed, and care for all of the boys the Authority can accommodate between now and July I, I943, and to take care of all overhead and operating expenses.

To some persons this brief record of accomplishments may seem to amount to very little. One national authority has advised me that everything the Authority has done to date should have been done by some agency already in existence. Perhaps that national authority is correct, but the interesting thing about it is that no existing agency even tried to do what the Authority has done to date. What the fate of the California Authority will be of course rests with the Governor and the coming session of the legislature. At the present writing the Authoriy seems to have more support than it did when the act was passed.

It seems to me that for the first time we have an agency which can give an over-all picture of youth crime and youth delinquency; for the first time we have an agency which can make every facility, both public and private, which exists within the state available to every county, to every court, and to every young man and woman; for the first time we have an agency which can consistently promote standards of case work and of personnel and of institutional and agency programs; for the first time we have an agency which, with a minimum of red tape, can treat offenders as individuals; for the first time we have an agency which can promote a worth-while delinquency and crime prevention program on a statewide basis. 


\section{Appendix: Survey of Crimtnal Cases Involving Youth in California Courts (Excluding Juvénile Courts) In I940}

The tables below represent a survey for the calendar year 1940 of 14,516 criminal cases against youths of the age of 22 years or less in the superior and inferior California courts (other than juvenile courts) in counties having a population of 5,894, orr (or $85 \%$ ) of a total state population of $6,907,387$ in the $x 94^{\circ}$ census. The survey covered youths apprehended in 1940, following their cases to completion. Charges are those made at time of apprehension.

Table I. Original Charges and Convictions in the Superior Court

(Charges are indicated in bold-face figures; convictions, in light-face figures.)

\begin{tabular}{|c|c|c|c|c|c|c|c|c|c|c|c|c|c|c|}
\hline \multirow{2}{*}{ Penal Code Offense } & \multicolumn{14}{|c|}{ Age Group } \\
\hline & \multicolumn{2}{|c|}{ 13-17 } & \multicolumn{2}{|r|}{18} & \multicolumn{2}{|r|}{19} & \multicolumn{2}{|c|}{20} & \multicolumn{2}{|r|}{21} & \multicolumn{2}{|r|}{22} & \multicolumn{2}{|c|}{ Totals } \\
\hline rson & & & & & & 2 & 1 & 1 & 2 & 2 & 2 & 2 & & 6 \\
\hline sen & & & 1 & 2 & 5 & 1 & 2 & 5 & 1 & 1 & 1 & 1 & 6 & 14 \\
\hline ssault with deadly weapon & ( & & & 3 & 8 & 8 & 5 & 3 & & 4 & & 5 & 28 & 22 \\
\hline Attem & & & & 1) & & 1) & 2 & 2 & 2 & 2 & 3 & 1 & 9 & 6 \\
\hline Attempted robbery. & 1 & & & 3 & 6 & 6 & 3 & 2 & 6 & 2 & 3 & 2 & 22 & 14 \\
\hline igamy... & & & & & & & & & & 2 & 1 & 1 & 4 & 3 \\
\hline urg & s & & 3) 64 & $4 \quad 29$ & 9 & $6 \quad 39$ & 991 & 41 & 81 & 1) 46 & 6 & $\begin{array}{l}6 \\
62\end{array}$ & 402 & 190 \\
\hline urg & 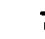 & & 1 & 3 & 2 & $2 \quad 10$ & & 3 & 3 & 9 & 1 & 9 & 7 & 37 \\
\hline Burg & & & 1 & 30 & & \begin{tabular}{l|l}
2 & 41
\end{tabular} & 2 & $\begin{array}{l}2 \\
2\end{array} 42$ & 4 & 4) 29 & 1 & 1] 34 & 9 & 177 \\
\hline Con & & & & 9 & \begin{tabular}{l|l}
9 & 13
\end{tabular} & 3) 14 & $\mathbf{g}$ & 9 & 1) 11 & 1) 14 & 6 & 7 & 46 & 55 \\
\hline Con & & & & 1 & 1 & 1 & 1 & & 1 & 1 & 1 & 1 & 4 & 4 \\
\hline Crim & & & 1 & 1 & 1 & 1] & 3 & 2 & 1 & 1 & 3 & 3 & 9 & 7 \\
\hline scar & & & 6 & 6 & 6 & 6 & 8 & 8 & 2 & 3 & 8 & 7 & 30 & 31 \\
\hline Forgery & & & 17 & 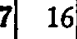 & 6) 21 & 1 21 & 1| 27 & $\begin{array}{l}7 \\
7\end{array} 25$ & \begin{tabular}{l|l}
5 & 34 \\
$r$
\end{tabular} & \begin{tabular}{l|l}
4 & 33
\end{tabular} & \begin{tabular}{l|l}
3 & 32 \\
-1
\end{tabular} & $\begin{array}{l}32 \\
22\end{array}$ & 131 & 127 \\
\hline Granc & 2 & re & 1) 80 & 0 27 & $\begin{array}{ll}76 \\
7\end{array}$ & $6 \quad 31$ & 1) 65 & 5. 26 & 6 6 60 & 034 & $4 \quad 38$ & $\begin{array}{ll} & 24\end{array}$ & 321 & 143 \\
\hline Grand theft $\rightarrow$ & & & 2 & 2 & 4 & 4 & 1 & $1]$ & 2 & 2 & & & 9 & 7 \\
\hline tel. lines. & & & 4 & 4 & 4 & & & & & & & & 4 & 4 \\
\hline Juvenile Court Law & & & & 5 & 5 & 5 & 5 & 2 & 2 & & & & & 12 \\
\hline Kid & & & 3 & 3 & 3 & 3 & 3 & 2 & 4 & 2 & 3 & & 16 & 5 \\
\hline ping for & & & 1 & 1) & 1 & 1] & & & & & 2 & & 4 & 1 \\
\hline 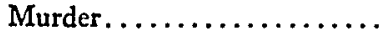 & & & 2 & 2 & 1 & 1 ] & & & 2 & 2 & 3 & & 8 & 2 \\
\hline Nar & & & 1 & 1 & 4 & 4 & 5 & 5 & 4 & 4 & 7 & 7 & 21 & 21 \\
\hline Negli & & & & & 1 & 1 & & & 2 & 2 & 3 & 3 & 6 & 6 \\
\hline Not & & & 7 & 3 & 1 & 5 & 2 & 2 & 5 & 5 & 5 & 4 & 20 & 19 \\
\hline Pet & & & 1 & 3 & 4 & 4) 11 & 3 & 9 & 2 & 5 & 3 & 10 & 13 & 38 \\
\hline Pimpi & & & & & 1 & 1 & 2 & & & 2 & 2 & & 5 & 3 \\
\hline Pool selling and bookmaking.. & & & & & & & & & 1 & 1 & 3 & 3 & 4 & 4 \\
\hline Rape & & & 10 & 8 & $3 \mid 15$ & $5 \mid 13$ & 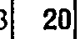 & 0 17 & 13 & $\begin{array}{l}3 \\
3\end{array}$ & 13 & \begin{tabular}{l|l}
33 \\
13
\end{tabular} & 71 & 63 \\
\hline $\operatorname{Rec}$ & & & ? & 3 & 1 & 1 & 5 & 6 & 2 & 2 & 6 & 6 & 17 & 18 \\
\hline Rol & 4 & 2 & 29 & 7 & 74 & 4) 11 & 1. 27 & 7) 10 & ) 32 & $2 \quad 13$ & 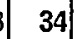 & 4 & 170 & 47 \\
\hline Robbery 1s & & & 1 & 9. & 2 & 7 & 2 & 9 & 2 & 213 & 3 & 17 & 9 & 55 \\
\hline Robbery 2nd degres & & & & 3 & & 6 & & 3 & & 5 & & 6 & & 23 \\
\hline & & & & & & & 1] & 1 & 3 & 2 & & & 4] & 3 \\
\hline Sim & & & 3 & & & & 2 & & & & & & 5 & \\
\hline Other penal & 1 & 1 & 3 & 2 & 1 & I) & 6 & 5 & 2 & 2 & 6 & 6 & 19 & 16 \\
\hline Totals under Penal Code. & 14 & 10 & 258 & 186 & 308 & \begin{tabular}{|l|l|}
3 & 249
\end{tabular} & 297 & 242 & 289 & 256 & 274 & & & \\
\hline
\end{tabular}


TABLE I. (Continued)

\begin{tabular}{|c|c|c|c|c|c|c|c|c|c|c|c|c|c|c|}
\hline \multirow{2}{*}{ Vehicle Code Offense } & \multicolumn{14}{|c|}{ AGE Group } \\
\hline & \multicolumn{2}{|c|}{$13-17$} & \multicolumn{2}{|c|}{18} & \multicolumn{2}{|c|}{19} & \multicolumn{2}{|c|}{20} & \multicolumn{2}{|c|}{21} & \multicolumn{2}{|c|}{22} & \multicolumn{2}{|c|}{ Totals } \\
\hline $\begin{array}{l}\text { Accidents-death or injuries.. } \\
\text { Negligent homicide........... } \\
\text { Drunken driving-felony..... } \\
\text { Drunken driving-misdemean. } \\
\text { Theft or unlawful taking..... }\end{array}$ & 1 & & $\begin{array}{r}2 \\
2 \\
1 \\
75\end{array}$ & $\begin{array}{l}1 \\
1\end{array}$ & $\begin{array}{r}5 \\
1 \\
3 \\
85\end{array}$ & $\begin{array}{r}4 \\
1 \\
2 \\
1 \\
77\end{array}$ & \begin{tabular}{r|}
3 \\
2 \\
3 \\
1 \\
50
\end{tabular} & $\begin{array}{r}2 \\
1 \\
1 \\
3 \\
61\end{array}$ & $\begin{array}{r}3 \\
4 \\
2 \\
5 \\
59\end{array}$ & $\begin{array}{r}2 \\
4 \\
2 \\
1 \\
60\end{array}$ & $\begin{array}{r}11 \\
2 \\
4 \\
1 \\
34\end{array}$ & $\begin{array}{r}11 \\
1 \\
3 \\
2 \\
39\end{array}$ & $\begin{array}{r}124 \\
11 \\
12 \\
8 \\
304\end{array}$ & $\begin{array}{r}20 \\
8 \\
8 \\
7 \\
312\end{array}$ \\
\hline Totals under Vehicle Code. & 1 & & 80 & 77 & 94 & 85 & 59 & 68 & 73 & 69 & 52 & 56 & 359 & 355 \\
\hline Totals under both codes. & 15 & 10 & 338 & 263 & 402 & 334 & 356 & 310 & 362 & 325 & 326 & 29 & 1799 & 1538 \\
\hline
\end{tabular}

Charges and convictions in less than 4 cases: Attempted grand theft $=2,1$; Attempted murder $=3,2$; Attempted rape $=3,1$; Crimes against nature $=2,1$; Deadly Weapons Act $=1,1$; Failure to provide $=$ 2, 2; Fictitious checks = 2, 2; Grand theft, animals $=0,3$; Incest $=1,1$; Malicious mischief $=0,1$; Manslaughter $=1,2 ;$ Mayhem $=2,2 ;$ Murder, 2nd Degree $=0,1 ;$ Pawnbrokers registry $=2$, 1; Resisting an officer $=1,1$; Vagrancy $=0,2$; Other state codes $=1,3$; Accidents involving property damage $=0,3$.

\section{Table II. Original Charges and Convictions in Inferior Courts}

(Charges are indicated in bold-face figures; convictions, in light-face figurcs.)

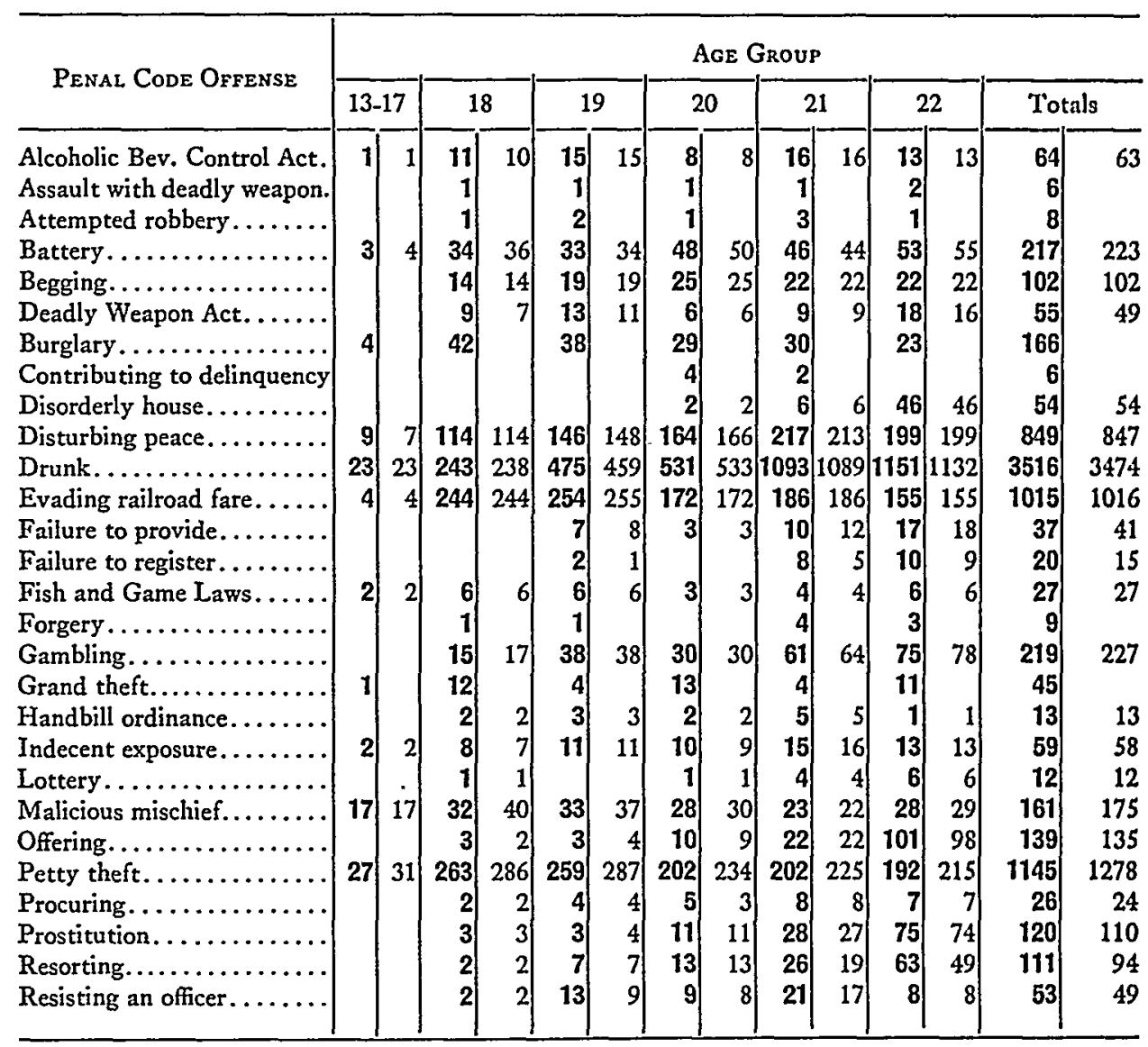


TAble II. (Continued)

\begin{tabular}{|c|c|c|c|c|c|c|c|c|c|c|c|c|c|c|}
\hline \multirow{2}{*}{ Ofrense } & \multicolumn{14}{|c|}{ AGE Group } \\
\hline & \multicolumn{2}{|c|}{$13-17$} & \multicolumn{2}{|c|}{18} & \multicolumn{2}{|c|}{19} & \multicolumn{2}{|c|}{20} & \multicolumn{2}{|c|}{21} & \multicolumn{2}{|c|}{22} & \multicolumn{2}{|c|}{ Totals } \\
\hline Scalping. & & & 1 & & & 1 & 2 & & 1 & & 3 & & 7 & 2 \\
\hline Selling without licenc & & & 7 & 7 & 3 & 2 & 4 & 4 & 6 & 5 & $\mathbf{9}$ & 9 & 29 & 27 \\
\hline Soliciting....... & & & & & 4 & & 2 & 2 & 5 & 5 & 15 & 15 & 26 & 26 \\
\hline Unemployment Reserve Ac & & & & & & & 3 & 3 & 3. & 3 & 6 & 6 & 12 & 12 \\
\hline Vagrancy, idle and late hrs. & 5 & 6 & 264 & 258 & 347 & 369 & 283 & 293 & 424 & 428 & 545 & 550 & 1868 & 1904 \\
\hline Vagrancy, lewd............ & 1) & 1 & 16 & 15 & 17 & 13 & 17 & 17 & 35 & 40 & 59 & 59 & 145 & 145 \\
\hline Vagrancy, roamer. & 8 & 8 & 295 & 295 & 300 & 301 & 233 & 234 & 271 & 271 & 268 & 268 & 1375 & 1377 \\
\hline Vagrancy, sleep & & & 28 & 28 & 28 & 28 & 31 & 31 & 38 & 38 & 36 & 37 & 161 & 162 \\
\hline Other city ordinances & 5 & 5 & 43 & 39 & 71 & 70 & 67 & 69 & 62 & 64 & 64 & 67 & 312 & 314 \\
\hline Other county ordinances & & & 12 & 13 & 12 & 17 & 12 & 12 & 11 & 12 & 14 & 14 & 61 & 68 \\
\hline Other $\mathrm{p}$ & 1 & 1 & 21 & 19 & 30 & 26 & 36 & 36 & 44 & 39 & 42 & 36 & 174 & 157 \\
\hline Other & 1 & 1 & 2 & 2 & 1 & 1 & 7 & 7 & & & 1 & 1 & 12 & 12 \\
\hline Totals & 114 & 113 & 1754 & 1709 & 2203 & 2192 & 2028 & 2027 & 2976 & 2940 & 3361 & 3311 & 12,436 & 12,292 \\
\hline VeHICLE CODE O & & & & & & & & & & & & & & \\
\hline Driving when license denied & & & 5 & 4 & 8 & 8 & 6 & 6 & 4 & 4 & 12 & 11 & 35 & 33 \\
\hline idents-death or injuries & & & & & 1 & 1 & 2 & 1 & 2 & 2 & 5 & 4 & 10 & 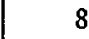 \\
\hline ecidents_property. & & & 1 & 1 & 13 & 12 & 3 & 3 & 6 & 6 & 14 & 14 & 37 & 30 \\
\hline Failure to inform or aid. . & & & & & 2 & 2 & & & 1 & 1 & 3 & 3 & 6 & 6 \\
\hline Drunken driving-felony... & & & & & 1 & & 1 & & 6 & & 4 & & 12 & \\
\hline Drunken driving-misdem & & & 26 & 26 & 75 & 71 & 82 & 79 & 162 & 157 & 200 & 198 & 545 & 531 \\
\hline Theft or unlawful taking... & & & 6 & & 10 & & 7 & & 7 & & 3 & & 33 & \\
\hline Tampering with vehicle.... & & & 27 & 23 & 23 & 24 & 22 & 24 & 9 & 13 & 7 & 6 & 88 & 90 \\
\hline Reckless driving... & & & 68 & 69 & 77 & 79 & 82 & 85 & 59 & 61 & 56 & 61 & 350 & 363 \\
\hline Reckless driving-injury & 8 & 8 & & & & & 2 & $?$ & 1 & 2 & 1 & 1 & 4 & \\
\hline Totals under Vehicle Code. & 8 & 8 & 133 & 123 & 210 & 197 & 207 & 200 & 257 & 246 & 305 & 298 & 1120 & 1072 \\
\hline & 1120 & & 1887 & & 413 & & 233 & 222 & & & & & 55 & 3,364 \\
\hline
\end{tabular}

Charges and convictions in less than 4 cases: Public meeting $=1,0 ;$ Receiving stolen property $=1,0$; Rape: 1, 0; Robbery $=3,0$; Assault $=0,2$; Failure to notify on striking unattended vehicle $=1$, 1; Failure to report accident: 1,1 .

Table III. Distribution by Race

\begin{tabular}{|c|c|c|c|c|c|c|c|}
\hline \multirow{2}{*}{ RACE oR COLOR } & \multicolumn{7}{|c|}{ Age Group } \\
\hline & $13-17$ & 18 & 19 & 20 & 21 & 22 & Total* \\
\hline White. & 104 & 1542 & 1958 & 1767 & 2471 & 2767 & 10,609 \\
\hline Mexican. & 14 & 313 & 467 & 448 & 570 & 611 & 2423 \\
\hline Negro.. & 8 & 167 & 231 & 205 & 277 & 344 & 1232 \\
\hline Filipino.. & & 4 & 2 & 2 & 5 & 3 & 16 \\
\hline Other... & 5 & 25 & 28 & 37 & 61 & 80 & 236 \\
\hline Totals... & 131 & 2051 & 2686 & 2459 & 3384 & 3805 & 14,516 \\
\hline
\end{tabular}

${ }^{*}$ Males, 13,214 cases; Females, 1302 cases. 
TABle IV. SENTENCES IMPOSED

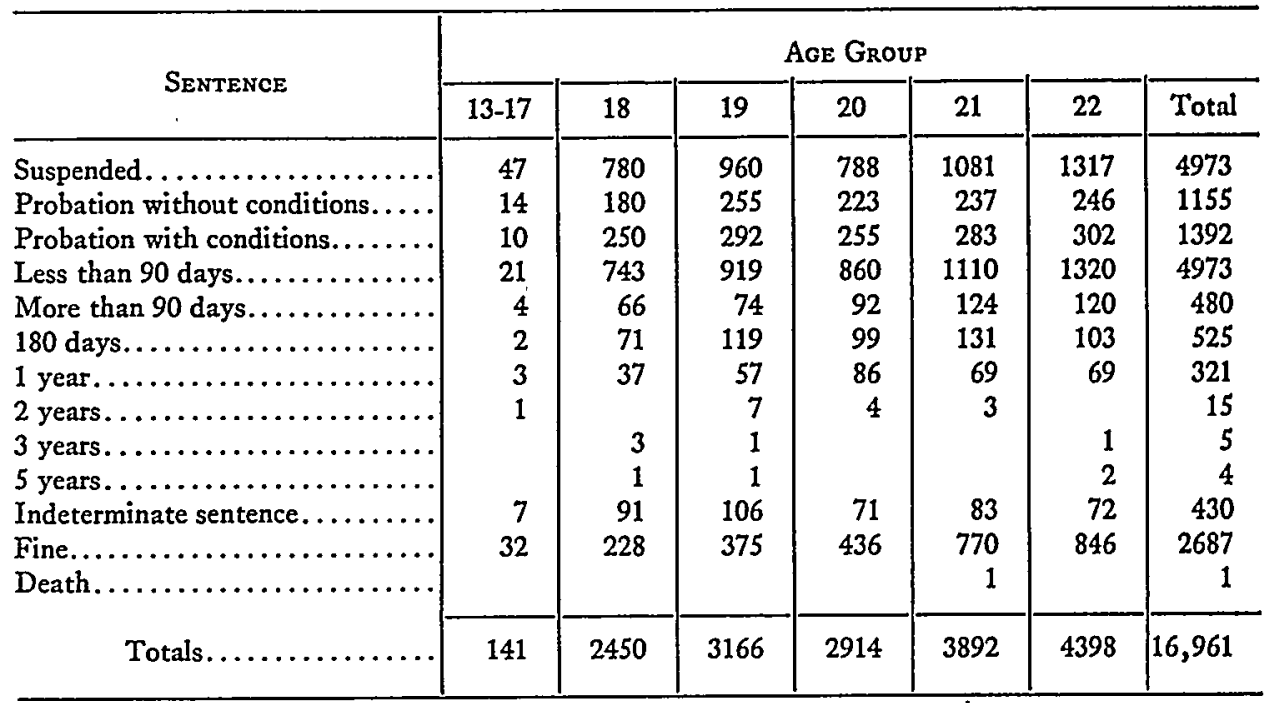

Table V. Place of Detention

\begin{tabular}{|c|c|c|c|c|c|c|c|}
\hline \multirow{2}{*}{ Place or Detention } & \multicolumn{7}{|c|}{ AGE GROUP } \\
\hline & $13-17$ & 18 & 19 & 20 & 21 & 22 & Total \\
\hline City jail. & 5 & 466 & 565 & 535 & 747 & 857 & 3175 \\
\hline County jail.. & 23 & 436 & 580 & 574 & 653 & 726 & 2992 \\
\hline San Quentin State Prison. & 3 & 28 & 43 & 49 & 74 & 63 & 260 \\
\hline Folsom State Prison ....... & & & 1 & 2 & 5 & 8 & 16 \\
\hline Preston School of Industry........ & 3 & 48 & 55 & 15 & 2 & 1 & 124 \\
\hline Ventura School for Girls........... & & 1 & & & & & 1 \\
\hline Tehachapi Institution for Women. & & & & 1 & 1 & 2 & 4 \\
\hline Forestry camp................. & 3 & 15 & 10 & 2 & & & 30 \\
\hline Released to Probation Officer.... & 20 & 227 & 275 & 234 & 264 & 270 & 1290 \\
\hline Road camp.................. & 1 & 18 & 30 & 34 & 39 & 30 & 152 \\
\hline Other.................... & 73 & 812 & 1127 & 1013 & 1599 & 1848 & 6472 \\
\hline Totals. & 131 & 2051 & 2686 & 2459 & 3384 & 3805 & 14,516 \\
\hline
\end{tabular}

